\title{
PENGARUH SISTEM OLAH TANAH DAN APLIKASI HERBISIDA TERHADAP POPULASI DAN BIOMASSA CACING TANAH PADA PERTANAMAN UBI KAYU (Manihot utilissima)
}

\author{
Yetti Komala Sari, Ainin Niswati, M.A. Syamsul Arif \& Sri Yusnaini \\ Jurusan Agroteknologi, Fakultas Pertanian Universitas Lampung \\ Jl.Prof. Soemantri Brodjonegoro, No.1, Bandar Lampung 35145 \\ E-mail: yettikomala@gmail.com
}

\begin{abstract}
ABSTRAK
Ubi kayu merupakan tanaman pangan yang banyak dibudidayakan di Provinsi Lampung. Mayoritas petani ubi kayu menerapkan sistem olah tanah intensif beserta aplikasi herbisida kimia dengan anggapan lebih efisien waktu, tenaga, dan biaya namun melupakan dampak negatifnya terhadap kesuburan lahan Penelitian ini bertujuan untuk mengetahui pengaruh sistem olah tanah dan aplikasi herbisida terhadap populasi dan biomassa cacing tanah pada pertanaman ubi kayu (Manihot utilissima) di Lahan Lapangan Terpadu Fakultas Pertanian, Universitas Lampung. Percobaan dirancang menggunakan RAK dengan dua faktor yaitu sistem olah tanah $(\mathrm{T})$ dan aplikasi herbisida $(\mathrm{H})$. Sistem olah tanah terdiri dari olah tanah intensif $\left(\mathrm{T}_{1}\right)$ dan olah tanah minimum $\left(\mathrm{T}_{2}\right)$, sedangkan aplikasi herbisida terdiri dari tanpa aplikasi herbisida $\left(\mathrm{H}_{0}\right)$ dan aplikasi herbisida $\left(\mathrm{H}_{1}\right)$. Herbisida yang digunakan yaitu herbisida berbahan aktif isopropilamina glifosat + isopropilamina 2,4 D dengan dosis yang digunakan yaitu $160 \mathrm{ml} / 1$ tangki (1 tangki=16 liter air). Data yang diperoleh diuji dengan analisis ragam dan dilanjutkan dengan uji BNT. Hasil penelitian menunjukkan bahwa sistem olah tanah tidak berpengaruh terhadap populasi dan biomassa cacing tanah, namun perlakuan herbisida berpengaruh terhadap populasi cacing tanah pada pengamatan 0 BST (sebelum tanam), dan uji BNT menunjukkan bahwa populasi cacing tanah lebih tinggi pada lahan yang tidak diaplikasikan herbisida. Populasi dan biomassa cacing tanah ditemukan lebih tinggi pada lapisan tanah $0-10 \mathrm{~cm}$ dan identifikasi cacing tanah di laboratorium menunjukkan bahwa cacing tanah yang ditemukan yaitu dari famili Megascolecidae genus Pheretima. Uji korelasi menunjukkan bahwa kadar air tanah berpengaruh terhadap populasi maupun biomassa cacing tanah.
\end{abstract}

Kata Kunci : Aplikasi Herbisida, Cacing Tanah, Olah Tanah Intensif, Olah Tanah Minimum, Ubi Kayu

\section{PENDAHULUAN}

Pengolahan tanah merupakan salah satu bentuk kegiatan dalam persiapan lahan yang biasa dilakukan oleh petani. Tujuan kegiatan pengolahan tanah yaitu selain untuk mengendalikan gulma juga meningkatkan produksi, namun tanpa disadari dalam jangka panjang olah tanah intensif berdampak meningkatkan degradasi lahan dan pada akhirnya lahan menjadi tidak produktif (Wardoyo, 2008).

Kegiatan olah tanah dalam persiapan lahan biasanya diikuti dengan kegiatan pengendalian gulma pada lahan. Pengendalian gulma pada lahan yang cukup luas biasanya dilakukan secara kimiawi yaitu menggunakan herbisida kimia sehingga gulma lebih cepat diatasi. Herbisida kimia memiliki bahan aktif yang dapat mempermudah dan mempercepat proses kematian gulma. Bahan aktif yang terkandung di dalam herbisida dapat teresidu di tanah, sehingga tidak hanya bersifat toksin pada gulma tetapi juga dapat mempengaruhi aktivitas biota tanah. Hasil penelitian Emalinda (2003) menunjukkan bahwa peningkatan dosis herbisida berbahan aktif glifosat yang diaplikasikan pada media tanah dalam polybag yang ditanami tanaman kedelai berpengaruh nyata terhadap penurunan populasi dan keragaman biota tanah. Biota tanah merupakan salah satu indikator kesuburan tanah, karena biota tanah berperan dalam proses dekompossi bahan organik. Salah satu biota tanah yang berperan dalam proses dekomposisi bahan organik adalah cacing tanah. Cacing tanah merupakan makrofauna tanah yang tidak hanya berperan sebagai agen dekomposisi tetapi juga berkontribusi dalam siklus unsur hara yang terjadi di dalam tanah (Ansyori, 2004). Cacing tanah secara tidak langsung juga membantu pengolahan tanah secara alami melalui aktivitas geraknya di dalam tanah yaitu membuat lubang-lubang sebagai komposisi ruang pori makro tanah yang dapat mendukung perbaikan kondisi tanah. 
Provinsi Lampung merupakan sentral produksi tanaman ubi kayu atau singkong. Mayoritas petani di Lampung memilih tanaman ubi kayu sebagai tanaman budidaya dengan teknik budidaya yang diterapkan adalah olah tanah intensif dan aplikasi herbisida. Teknik budidaya tersebut dapat mempengaruhi kehidupan biota tanah sebagai agen kesuburan tanah. Munculnya masalah kesuburan tanah yang disebabkan oleh teknik budidaya yang kurang tepat tersebut maka akan dilaksanakan penelitian dengan tujuan untuk menghitung populasi dan biomassa cacing tanah akibat diterapkannya sistem olah tanah dan aplikasi herbisida pada lahan pertanaman ubi kayu dan untuk mempelajari interaksi antara sistem olah tanah dan aplikasi herbisida terhadap populasi dan biomassa cacing tanah pada pertanaman ubi kayu.

\section{BAHAN DAN METODE}

Penelitian ini dilaksanakan pada bulan Mei 2014 - April 2015 pada lahan pertanaman ubi kayu, Fakultas Pertanian, Universitas Lampung. Analisis cacing tanah dan contoh tanah dilakukan di Laboratorium Ilmu Tanah, Fakultas Pertanian, Universitas Lampung.

Penelitian ini dirancang secara faktorial dalam Rancangan Acak Kelompok (RAK) yang terdiri dari dua faktor yaitu sistem olah tanah (T) dan aplikasi herbisida $(\mathrm{H})$. Sistem olah tanah terdiri dari olah tanah minimum $\left(\mathrm{T}_{1}\right)$ dan olah tanah intensif $\left(\mathrm{T}_{2}\right)$. Sedangkan aplikasi herbisida terdiri dari tanpa aplikasi herbisida $\left(\mathrm{H}_{0}\right)$ dan aplikasi herbisida $\left(\mathrm{H}_{1}\right)$. Dengan demikian percobaan ini terdiri dari empat kombinasi perlakuan yaitu:

$\mathrm{T}_{1} \mathrm{H}_{0}=$ olah tanah minimum + tanpa aplikasi herbisida $\mathrm{T}_{1} \mathrm{H}_{1}=$ olah tanah minimum + aplikasi herbisida $\mathrm{T}_{2} \mathrm{H}_{0}=$ olah tanah intensif + tanpa aplikasi herbisida $\mathrm{T}_{2} \mathrm{H}_{1}=$ olah tanah intensif + aplikasi herbisida

Data yang diperoleh dianalisis dengan sidik ragam pada taraf $5 \%$ dan rerata nilai tengah dari data diuji dengan uji BNT pada taraf 5\%. Hubungan antara populasi dan biomassa cacing tanah dengan $\mathrm{C}$-organik,
$\mathrm{pH}$, kelembaban, kadar air dan suhu tanah diketahui dengan uji korelasi.

Pengamatan cacing tanah dilakukan sebanyak 4 kali berdasarkan umur tanaman singkong yaitu 0 BST (Bulan Setelah Tanam) bulan Mei 2014, selanjutnya pengamatan dilakukan kembali pada 3 BST, 6 BST, dan 11 BST (Agustus 2014, November 2014, dan April 2015. Pengamatan cacing tanah dilakukan sebelum lahan diaplikasikan herbisida. Cacing tanah diamati dengan menggunakan metode penghitungan dengan tangan (hand sorting). Proses pengambilan cacing tanah yaitu diawali dengan menandai tanah dengan bingkai logam berukuran $50 \mathrm{~cm} \times 50 \mathrm{~cm}$, kemudian tanah digali dan diamati populasi cacing tanah pada lapisan $0 \mathrm{~cm}-10$ $\mathrm{cm}, 10 \mathrm{~cm}-20 \mathrm{~cm}$, dan $20 \mathrm{~cm}-30 \mathrm{~cm}$. Pada lubang galian $30 \mathrm{~cm}$ diberikan cairan mustard $0,7 \%$ sebanyak $1 \mathrm{~L}$ untuk merangsang cacing tanah keluar ke permukaan tanah. Cacing tanah yang putus dihitung sebagai 1 cacing utuh. Cacing tanah yang berukuran cukup besar atau cacing dewasa setelah dicuci dan ditimbang kemudian dimasukkan ke dalam tabung bertutup yang berisi formalin untuk diidentifikasi jenisnya. Identifikasi contoh cacing tanah yang diperoleh dilakukan di laboratorium menurut penciri morfologi tubuhnya dengan panduan General Earthworm Diagram. Bersamaan dengan pengamatan cacing tanah dilakukan pengambilan contoh tanah untuk dianalisis di laboratorium. Analisis yang dilakukan yaitu kadar air tanah dengan metode gravimetrik, $\mathrm{pH}$ tanah dengan metode elektrometrik, Corganik tanah dengan metode Wakley and Black, dan suhu tanah dengan Thermometer yang langsung diukur di lahan pada saat pengamatan cacing tanah.

\section{HASIL DAN PEMBAHASAN}

Hasil analisis statistik pada setiap perlakuan terhadap populasi dan biomassa cacing tanah setiap bulan pengamatan dapat dilihat pada Tabel 1, menunjukkan bahwa perlakuan sistem olah tanah tidak berpengaruh terhadap populasi maupun biomassa cacing tanah pada setiap bulan pengamatan, sedangkan aplikasi

Tabel 1. Rekapitulasi hasil analisis ragam pengaruh sistem olah tanah $(\mathrm{T})$ dan aplikasi herbisida $(\mathrm{H})$ terhadap populasi dan biomassa cacing tanah (BC) pada pertanaman ubi kayu.

\begin{tabular}{|c|c|c|c|c|c|c|c|c|}
\hline \multirow{3}{*}{ Perlakuan } & \multicolumn{8}{|c|}{ Variabel Pengamatan } \\
\hline & \multicolumn{2}{|c|}{$0 \mathrm{BST}$} & \multicolumn{2}{|c|}{3 BST } & \multicolumn{2}{|c|}{$6 \mathrm{BST}$} & \multicolumn{2}{|c|}{$11 \mathrm{BST}$} \\
\hline & $\mathrm{PC}$ & $\mathrm{BC}$ & $\mathrm{PC}$ & $\mathrm{BC}$ & $\mathrm{PC}$ & $\mathrm{BC}$ & $\mathrm{PC}$ & $\mathrm{BC}$ \\
\hline (T) & tn & tn & th & tn & th & tn & tn & $\operatorname{tn}$ \\
\hline$(\mathrm{H})$ & * & tn & tn & tn & tn & $\operatorname{tn}$ & tn & $\operatorname{tn}$ \\
\hline$(\mathrm{TxH})$ & th & th & th & tn & tn & $\operatorname{tn}$ & th & tn \\
\hline
\end{tabular}


herbisida berpengaruh terhadap populasi cacing tanah pada pengamatan 0 BST saja.

Hasil analisis statistika menunjukkan bahwa olah tanah tidak berpengaruh terhadap populasi cacing tanah. Hal ini disebabkan oleh belum adanya pengaruh dari sistem olah tanah yang diterapkan pada lahan pengamatan, sehingga kondisi tanah pada setiap petakan belum berbeda antara perlakuan sistem olah tanah minimum (OTM) maupun sistem olah tanah intensif (OTI). Secara statistik sistem olah tanah memang tidak mempengaruhi populasi cacing tanah, namun dapat dilihat pada Gambar 1 (a) bahwa pada lahan OTM populasi cacing tanah relatif lebih tinggi dibandingkan lahan OTI. Hal ini dikarenakan tanah pada lahan OTM lebih kaya bahan organik yang merupakan sumber makanan bagi cacing tanah dibandingkan lahan OTI. Bahan organik pada lahan OTM berasal dari serasah sisa tanaman jagung dan serasah gulma, sedangkan pada lahan OTI gulma dan serasah sisa tanaman jagung dibersihkan dari lahan. Menurut Rukmana (1999) tanah yang kaya bahan organik akan banyak dihuni oleh biota tanah, salah satunya yaitu cacing tanah.

Peningkatan populasi cacing tanah terjadi pada pengamatan 11 BST dibandingkan bulan pengamatan lainnya, hal ini disebabkan oleh pada pengamatan 11 BST kondisi tanaman sudah cukup tinggi yang menyebabkan kelembapan tanah pada lahan tersebut lebih terjaga dan mendukung untuk kehidupan cacing tanah, selain itu selang waktu aplikasi herbisida dengan pengamatan adalah 5 bulan sehingga gulma lebih banyak tumbuh dan sumber makanan cacing tanah pun lebih melimpah.

Hasil uji BNT taraf 5\% (Tabel 2) pada pengamatan 0 BST menunjukkan bahwa lahan yang pengendalian gulma nya menggunakan herbisida memiliki populasi cacing tanah lebih rendah dibandingkan lahan tanpa aplikasi herbisida. Hal ini disebabkan oleh pengamatan jumlah cacing tanah pada 0 BST dilakukan hanya 1 bulan setelah aplikasi herbisida, sedangkan pengamatan selanjutnya dilakukan dengan selang waktu 3-5 bulan setelah aplikasi. Dengan waktu 1 bulan diduga bahan aktif herbisida yang bersifat racun masih teresidu dalam jumlah yang banyak pada gulma yang merupakan sumber makanan bagi cacing tanah. Menurut Madani, dkk. (2013), bahan aktif glifosat yang teresidu pada pakan cacing kemudian dimakan oleh cacing tanah dapat berpengaruh terhadap perkembangbiakan cacing tanah karena bahan aktif tersebut bersifat toksin terhadap kokon yang menyebabkan kematian embrio.

Hasil analsis statistik menunjukkan bahwa sistem olah tanah dan aplikasi herbisida tidak berpengaruh nyata terhadap biomassa cacing tanah. Berdasarkan Gambar 1 (b), menunjukkan bahwa biomassa cacing tanah pada pengamatan 0 BST lebih tinggi pada petakan lahan $\mathrm{T}_{2}$ dibandingkan $T_{1}$, namun pada pengamatan selanjutnya
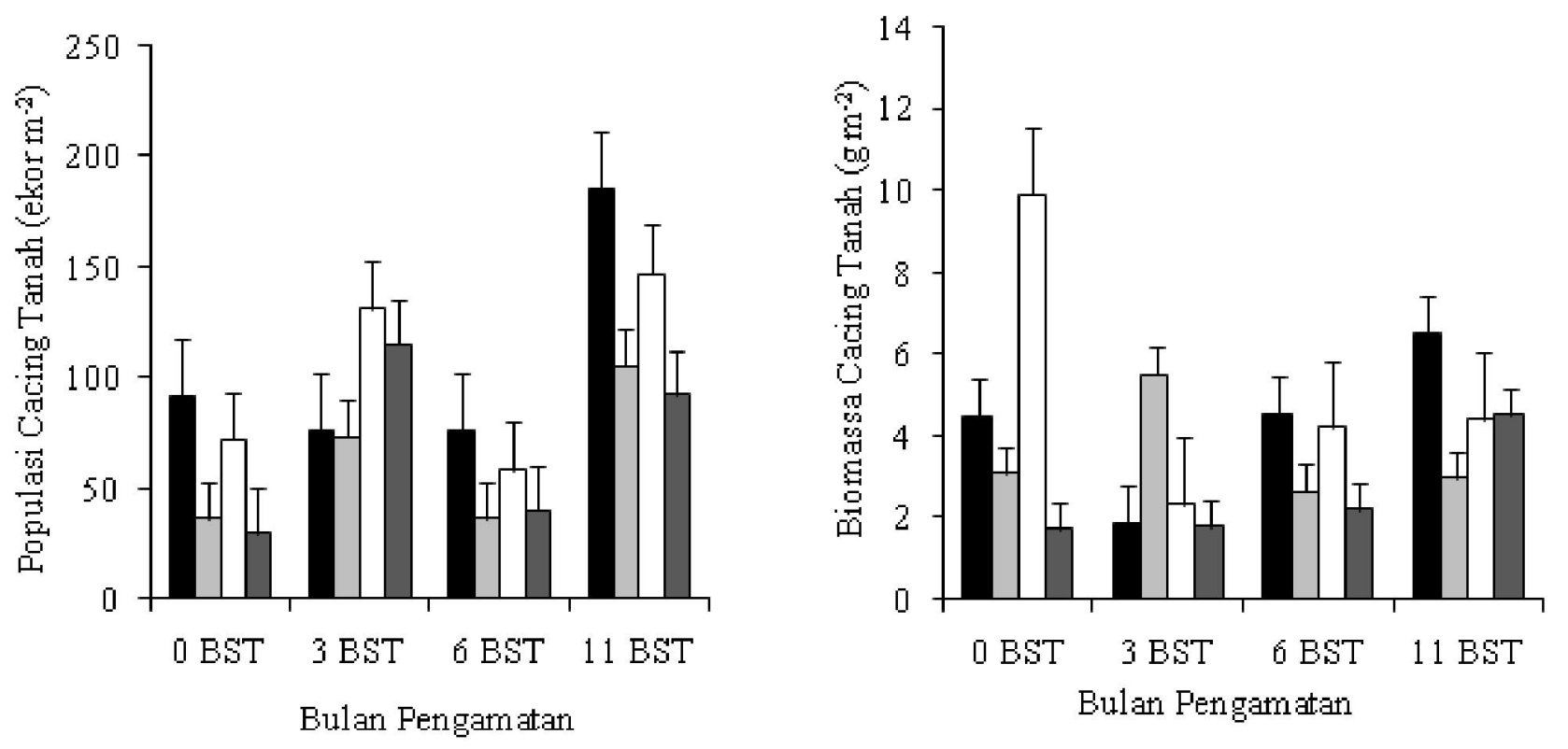

Gambar 1. (a) Populasi cacing tanah; (b) Biomassa cacing tanah; $\mathrm{T}_{1} \mathrm{H}_{0}(\boldsymbol{\square})=$ olah tanah minimum + tanpa aplikasi herbisida $; \mathrm{T}_{1} \mathrm{H}_{1}(\square)=$ olah tanah minimum + aplikasi herbisida; $\mathrm{T}_{2} \mathrm{H}_{0}(\square)=$ olah tanah intensif + tanpa aplikasi herbisida; $\mathrm{T}_{2} \mathrm{H}_{1}(\square)=$ olah tanah intensif + aplikasi herbisida; BST = bulan stetelah tanam; Tongkat pada grafik batang menunjukkan standar error. 
biomassa cacing tanah $T_{1}$ meningkat sedangkan pada petakan lahan $\mathrm{T}_{2}$ mengalami penurunan. Hal ini dikarenakan tanah pada lahan OTM lebih kaya bahan organik yang merupakan sumber makanan bagi cacing tanah dibandingkan lahan OTI. Bahan organik pada lahan OTM berasal dari serasah sisa tanaman jagung dan serasah gulma, sedangkan pada lahan OTI gulma dan serasah sisa tanaman jagung dibersihkan dari lahan. Menurut Rukmana (1999), tanah yang kaya bahan organik akan banyak dihuni oleh biota tanah, salah satunya yaitu cacing tanah.

Hasil pengamatan populasi cacing tanah per lapisan dan biomassa cacing tanah per lapisan menunjukkan bahwa baik populasi maupun biomassa cacing tanah lebih tinggi pada lapisan tanah teratas yaitu

Tabel 2. Pengaruh aplikasi herbisida terhadap populasi cacing tanah pada pengamatan 0 BST.

\begin{tabular}{lc}
\hline \multicolumn{1}{c}{ Perlakuan } & Populasi $\left(\right.$ ekor $\left.^{-2}\right)$ \\
\hline Tanpa Herbisida $\left(\mathrm{H}_{0}\right)$ & $86 \mathrm{a}$ \\
Aplikasi Herbisida $\left(\mathrm{H}_{1}\right)$ & $33 \mathrm{~b}$ \\
\hline BNT $_{0,05}$ & 37 \\
\hline
\end{tabular}

kedalaman $0-10 \mathrm{~cm}$. Hal ini disebabkan oleh lapisan tanah teratas merupakan lapisan tanah yang kaya akan bahan organik, sehingga banyak cacing tanah pada lapisan tersebut. Menurut Sugiyarto (2007), bahan organik tanaman merupakan salah satu faktor penentu tinggi rendahnya populasi makrofauna tanah.

Faktor lain yang berpengaruh terhadap populasi maupun biomassa cacing tanah yaitu perubahan lingkungan seperti $\mathrm{C}$-organik tanah, $\mathrm{pH}$ tanah, suhu tanah, dan kadar air tanah. ringkasan hasil uji korelasi (Tabel 3) menunjukkan bahwa kadar air tanah berpengaruh terhadap populasi cacing tanah pada pengamatan 6 BST dan berpengaruh terhadap bomassa cacing tanah pada pengamatan 11 BST. Hasil uji korelasi menunjukkan bahwa kadar air tanah berkorelasi positif terhadap populasi cacing tanah pengamatan $6 \mathrm{BST}$, namun berkorelasi negatif terhadap biomassa cacing tanah pengamatan $11 \mathrm{BST}$. Cacing tanah sangat sensitif dengan kelembapan tanah, karena kelembapan sangat dibutuhkan oleh cacing tanah untuk menjaga kulitnya agar dapat berfungsi normal yaitu untuk berespirasi. Berat tubuh cacing tanah terdiri dari 75-90\% air, sehingga kelembapan tempat hidupnya sangat penting, kisaran kelembapan optimum bagi cacing tanah yaitu

Tabel 3. Ringkasan hasil uji korelasi populasi cacing tanah $\left(\right.$ ekor $\left.\mathrm{m}^{-2}\right)$ dan biomassa cacing tanah $\left(\mathrm{g} \mathrm{m}^{-2}\right)$ dengan sifat kimia tanah pada lahan pertanaman ubi kayu.

\begin{tabular}{ccc}
\hline \multirow{2}{*}{ Variabel } & \multicolumn{2}{c}{ Koefisien korelasi (r) } \\
\cline { 2 - 3 } & Jumlah cacing tanah & Biomassa cacing tanah \\
\hline Analisis tanah 0 BST & $0,39^{\text {tn }}$ & $0,49^{\text {tn }}$ \\
C-organik & $0,21^{\text {tn }}$ & $0,51^{\text {tn }}$ \\
pH tanah & $0,18^{\text {tn }}$ & $0,31^{\text {tn }}$ \\
Kadar air Tanah & $0,36^{\text {tn }}$ & $0,01^{\text {tn }}$ \\
Suhu tanah & & \\
Analisis tanah 3 BST & $0,25^{\text {tn }}$ & $0,03^{\text {tn }}$ \\
C-organik & $0,19^{\text {tn }}$ & $0,21^{\text {tn }}$ \\
pH tanah & $0,46^{\text {tn }}$ & $-0,15^{\text {tn }}$ \\
Kadar air Tanah & $-0,29^{\text {tn }}$ & $0,01^{\text {tn }}$ \\
Suhu tanah & & \\
Analisis tanah 6 BST & $0,02^{\text {tn }}$ & $0,26^{\text {tn }}$ \\
C-organik & $0,37^{\text {tn }}$ & $0,24^{\text {tn }}$ \\
pH tanah & $0,79^{*}$ & $0,41^{\text {tn }}$ \\
Kadar air Tanah & $0,51^{*}$ & $0,41^{\text {tn }}$ \\
Suhu tanah & & \\
Analisis tanah 11 BST & $0.31^{\text {tn }}$ & $0,16^{\text {tn }}$ \\
C-organik & $0,28^{\text {tn }}$ & $0,49^{\text {tn }}$ \\
pH tanah & $-0,03^{\text {tn }}$ & $-0,64^{\text {tn }}$ \\
Kadar air Tanah & $-0,31^{\text {tn }}$ & $-0,21^{\text {tn }}$ \\
Suhu tanah & & \\
\hline
\end{tabular}


15-50\% (Rukmana, 1999). Bila kadar air tanah terlalu tinggi maka cacing tanah akan pergi untuk mencari tempat yang kelembapannya stabil sehingga kulitnya bisa berfungsi normal kembali.

Suhu berpengaruh terhadap populasi cacing tanah pada pengamatan 6 BST dan berkorelasi positif. Cacing tanah merupakan biota tanah yang sangat sensitif terhadap suhu lingkungan, namun cacing tanah masih dapat mentolerir suhu diatas $30^{\circ} \mathrm{C}$ bila didukung dengan kelembapan yang tinggi (Agustinus, 2009). Suhu yang terlalu rendah juga tidak disukai oleh cacing tanah, karena akan berdampak terhadap penetasan kokon cacing tanah.

Hasil identifikasi cacing tanah dewasa yang dilakukan berdasarkan seta dan klitelum diperoleh bahwa cacing tanah yang terdapat pada lahan tersebut merupakan jenis cacing tanah dari dari famili Megascolecidae yaitu genus Pheretima. Cacing Pheretima tergolong epigeik yaitu hidup pada tumpukan bahan organik di permukaan tanah (Edwards dan Bohlen, 1996 dalam Qudratullah, dkk., 2013). Cacing Pheretima memiliki warna tubuh abu-abu gelap kebiruan, dengan panjang tubuh berkisar antara $10-15 \mathrm{~cm}$, dengan jumlah segmen berkisar 92. Setiap segmen terdiri atas seta yang merupakan alat gerak, dan seta cacing jenis ini berkisar antara 50 sampai lebih dari 100 (Stephenson, 1930 dalam Shanty, 2006).

\section{KESIMPULAN}

Dari hasil penelitian dapat disimpulkan bahwa sistem olah tanah minimum dan sistem olah tanah intensif tidak mempengaruhi populasi dan biomassa cacing tanah pada musim tanam ke-2. Aplikasi herbisida menurunkan populasi cacing tanah pada 1 bulan setelah aplikasi herbisida yaitu pengamatan sebelum tanam (0 BST) namun tidak berpengaruh terhadap populasi dan biomassa cacing tanah pada pengamatan $3 \mathrm{BST}, 6 \mathrm{BST}$, dan 11 BST. Tidak terdapat interaksi antara sistem olah tanah dan aplikasi herbisida terhadap populasi dan biomassa cacing tanah. Populasi dan biomassa cacing tanah lebih tinggi pada tanah lapisan atas $(0-10 \mathrm{~cm})$ dibandingkan dengan tanah lapisan bawah. Kadar air tanah berpengaruh dan berkorelasi positif terhadap populasi cacing tanah, namun berkorelasi negatif terhadap biomassa cacing tanah. Hasil identifikasi cacing tanah ditemukan cacing tanah dari famili Megascolecidae yaitu genus Pheretima.

\section{DAFTAR PUSTAKA}

Agustinus, M. D. 2009. Tingkah Laku Cacing Tanah. www.kompas.com. Diakses pada tanggal: 3 Mei 2015.

Ansyori. 2004. Potensi cacing tanah sebagai alternatif bio-indikator pertanian berkelanjutan. Makalah Pribadi Falsafah Sains (PPS 702). Institut Pertanian Bogor. Bogor.

Emalinda, O., W. A. Prima, dan Agustian. 2003. Pengaruh herbisida glifosat terhadap pertumbuhan dan keragaman mikroorganisme dalam tanah serta pertumbuhan tanaman kedelai (Glicyne max. (L). Merr) pada Ultisol. Stigma. 11: 309-314.

Madani, Ramadhan, dan Gustina. 2013. Pengaruh herbisida isopropilamina glifosat terhadap fekunditas dan viabilitas kokon cacing tanah Pontoscolex corethrurus Fr. Mull. Jurnal Mahasiswa Pendidikan Biologi. 2: 175-182.

Qudratullah, H., Tri R.S., dan Ari H.Y. 2013. Keanekaragaman cacing tanah (Oligochaeta) pada tiga tipe di kecamatan Pontianak Kota. Jurnal Protobiont. 2 : 56 - 62.

Rukmana, R. 1999. Budidaya Cacing Tanah. Penerbit Kanisius. Yogyakarta. Hlm 28 - 29.

Shanty. 2006. Beberapa aspek biologic cacing tanah Pheretima darnleiensis (Fletcher). Skripsi. Institut Pertanian Bogor. Bogor.

Sugiyarto, Manan E., Edwl M., Yogi S., Eko H., dan Lily A. 2007. Preferensi berbagai jenis makrofauna tanah terhadap sisa bahan organik tanaman pada intensitas cahaya berbeda. Jurnal Biodiversitas. 7: 96 - 100.

Wardoyo, S.S. 2008. Aplikasi olah tanah konservasi dan pupuk $\mathrm{N}$ pada Entisol serta pengaruhnya terhadap serapan NPK tanaman jagung. Jurnal Agrin. $12 ; 227$ - 236. 